\title{
OSTALGIA I BEZPOWROTNOŚĆ W ŚRODKOWOEUROPEJSKIM KINIE PRZEŁOMU
}

\author{
DOBROCHNA DABERT ${ }^{1}$ \\ (Poznań)
}

Słowa-klucze: ostalgia, pamięć, film, transformacja, Europa Środkowo-Wschodnia

Key words: ostalgia, memory, film, transformation, Central-Eastern Europe

\begin{abstract}
Dobrochna Dabert, OSTALGIA I BEZPOWROTNOŚĆ W ŚRODKOWOEUROPEJSKIM KINIE PRZEŁOMU. „PORÓWNANIA” 11, 2012, Vol. XI, ss. 139-156, ISSN 1733-165X. Tekst poświęcony został ostalgii - zdeformowanej pamięci o komunizmie, która pojawiła się w krajach byłego bloku wschodniego, gdzie znalazła swoje odbicie $\mathrm{w}$ dyskursie publicznym, w debatach historycznych, politologicznych, w formach aktywności medialnej a także w sztuce literackiej i filmowej. Ostalgia przybiera zróżnicowane formy uwzględniające uwarunkowania lokalne: kształt i nasilenie powojennego reżimu, konteksty historyczne, społeczne, obyczajowe a także mentalnościowe. Cechy, które pozwalają oddać specyfikę ostalgicznej pamięci to: wybiórczość, niedokładność, niepełność, niedoskonałość. Jeśli ostalgia budowana jest na sentymencie do pewnych aspektów przeszłości to jej zaprzeczenie, które nazwać można bezpowrotnością znajduje swoje źródło w resentymentach do przeszłości, przejawiając się w niechęci do wspominania, ucieczką od przeszłości w prezentyzm, ale także sięgania do najciemniejszych doświadczeń czasów komunizmu. Tekst ujawnia zjawisko ostalgii i bezpowrotności odnalezione $\mathrm{w}$ filmach środkowoeuropejskich, zrealizowanych po przełomie 1989 roku.
\end{abstract}

\begin{abstract}
Dobrochna Dabert, OSTALGIA AND NON-REVERSIBILITY IN THE CENTRAL EUROPEAN CINEMA OF THE TURNING POINT. "PORÓWNANIA" 11, 2012, Vol. XI, pp. 139-156, ISSN 1733-165X. The text is dedicated to ostalgia - a deformed memory of communism which appeared in the countries of the former Eastern bloc where it is reflected in the public discourse, historical and politological debates, in forms of media activity but also in literary and cinema arts. Ostalgia assumes various forms which base on local conditions: the shape and intensity of the post-war regime, historical, social, moral and mental contexts. The features which allow to present the specificity of the ostalgic memory are: selectivity, inaccuracy and imperfection. If ostalgia is built on the sentiment towards some aspects of the past then its negation, which can be called non-reversibility,originates from resentiments towards the past and are visible in the
\end{abstract}

\footnotetext{
${ }^{1}$ Correspondence Address: dobro@amu.edu.pl
} 
unwillingness towards recollection, a flight from the past into presentism but also reaching the darkest experience of the communist times. The text reveals the phenomenon of ostalgia and non-reversibility found in Central European films produced after the breakthrough of 1989 .

Dyskusja nad przedstawieniami przeszłości w kinie środkowoeuropejskim po 1989 roku napotyka na problem pamięci, jako jednej z głównych organizatorek transformacyjnej narracji. Historiografia współczesna coraz intensywniej skupia się na kategorii pamięci zadając pytanie „w jaki sposób przeszłość jest zapamiętywana", odsuwając nieco z centrum zainteresowania tradycyjne podejście poszukujące odpowiedzi na pytanie, które zwykło się formułować w następujący sposób: „jak sprawy się rzeczywiście miały"2.

Tymczasem pamięć nie jest według Aleidy Assmann, zjawiskiem jednorodnym, raczej należałoby mówić o formach pamięci, które kształtowane są „według zasięgu czasowego i stabilności na trzech poziomach: pamięci jednostki, zbiorowości i kultury"3. Indywidualne wspomnienia budują pamięć zbiorowości, z której konstruowana jest pamięć kulturowa. Ta z kolei uzależniona jest od mediów jako nośników pamięci, ale także od instytucjonalnie zaplanowanej polityki pamięci. Badaczka podkreśla, iż pamiętanie jest "procesem rekonstruktywnym” dla którego punktem odniesienia jest teraźniejszość, która „prowadzi niechybnie do przesunięcia, deformacji, zniekształcenia, przewartościowania"4. Na praktyki pamiętania wpływ ma także zapominanie, niepamięć, wszelkie zniekształcenia i zafałszowania, które wynikają ze zmiennych „kontekstów zapotrzebowań:, które doprowadzić mogą do „przedefiniowania zapamiętanych treści” 5 .

To ostatnie zastrzeżenie ma dla nas szczególną wagę, bowiem interesować nas będzie problematyka nostalgii, która jest pamiętaniem uszkodzonym a jednocześnie, w szczególny sposób, niepamięcią. Do tego jeszcze nostalgii specyficznej, tej, którą narody byłego bloku wschodniego, niebawem po odzyskaniu niepodległości, zaczęły odczuwać na tyle silnie, że uczucie to znalazło swoje odbicie w dys-

${ }^{2}$ Zob. K. Wójcicki, Zagadnienie historiografii pamięci, http://kazwoy.wordpress.com/niemcy/ zagadnienie-historiografii-pamieci/; zob. też: B. Szacka, Czas przeszły pamięć mit. Warszawa 2006; J. Le Goff, History and Memory. Nowe York 1992; Teraźniejszość i pamięć przyszłości. Rozumienie historii w literaturze polskiej. Red. H. Gosk, A. Zieniewicz. Warszawa 2006; Wobec przeszłości: pamięć przeszłości jako element kultury wspótczesnej. Red. A. Szpociński. Warszawa 2005; A. Hankała, Wybiórczość ludzkiej pamięci. Warszawa 2001;

${ }^{3}$ A. Assmann, 1998 - Między historia a pamięcią. Przeł. M. Saryusz-Wolska, w: Pamięć zbiorowa i kulturowa. Wspótczesna perspektywa niemiecka. Red. M. Saryusz-Wolska. Kraków 2009, s. 158.

${ }^{4}$ A. Assmann, Przestrzenie pamięci. Formy i przemiany pamięci kulturowej. Przeł. P. Przybyła, w: Pamięć zbiorowa i kulturowa. Wspótczesna perspektywa niemiecka. Red. M. Saryusz-Wolska. Kraków 2009, s. 119.

${ }^{5}$ A. Assmann, Przestrzenie pamięci. Formy i przemiany pamięci kulturowej, op. cit., s. 120. 
kursie publicznym, w debatach historycznych, politologicznych, w formach aktywności medialnej, a także w sztuce literackiej, filmowej. Zniekształcona pamięć po komunizmie przybrała nazwę ostalgii. Termin ten zaczerpnięty został z języka niemieckiego (Ostalgie) stanowiąc grę słów Ost - wschód oraz Nostalgie.

Samo pojęcie powstało w Niemczech, stosunkowo wcześnie, w 1992 roku. Za pomysłodawcę terminu uznaje się drezdeńskiego artystę kabaretowego. Uwe Steimle, bo tak nazywał się artysta, swoje telewizyjnego show nazwał Ostalgia, bawiąc widzów żartami z niedawnej enerdowskiej przeszłości. Do dyskursu publicznego pojęcie weszło na stałe dopiero w 2003 roku po premierze filmu na motywach powieści Wolfganga Beckera Good Bye, Lenin.

Wprawdzie początkowo terminem tym próbowano jedynie zdefiniować problem postenerdowskiej uszkodzonej pamięci, zdominowanej przez nadchodzącą nostalgię za czasami lokalnego socjalizmu, niebawem okazało się, że zjawisko to dotknęło wiele krajów byłego bloku wschodniego. Musimy mieć świadomość, że ostalgia nie jest pojęciem jednoznacznym. Przybierała i przybiera zróżnicowane formy uwzględniając uwarunkowania lokalne: kształt i nasilenie powojennego reżimu, konteksty historyczne, społeczne, obyczajowe a także mentalnościowe. Jeśli chcielibyśmy wskazać na cechy, które pozwalają oddać specyfikę ostalgicznej pamięci, to byłyby to: wybiórczość, niedokładność, niepełność, niedoskonałość.

Część badaczy ${ }^{6}$ zajmujących się tym zjawiskiem wskazuje na "charakterystyczny stan pamięci", która jawi się jako swego rodzaju choroba pamięci wywołana, jak twierdzi Jurij Andruchowycz za sprawą „duchowych selekcji, umiejętnie coś utrwalających i tak samo sprawnie zacierających co innego"7. W efekcie pojawia się jakieś niedokładne wspomnienie rzekomego dobrobytu, poczucia bezpieczeństwa, spokoju, niewzruszonego ładu - zauważa ukraiński pisarz.

\section{PRZYCZYNY WYTWARZANIA SIĘ SELEKTYWNEJ PAMIĘCI}

Prawdopodobnie, jak zauważa Jurij Andruchowycz, powodem mogła być, między innymi, ścisła reglamentacja informacji powiązana z działaniami budującymi wizję nieustającego sukcesu socjalistycznych gospodarek. Lata wolności in-

${ }^{6}$ Węgierski historyk i pisarz Béla Nóvé podkreślił znaczenie kontekstu społecznego i politycznego, w jakim pojawiła się ostalgia: „Występująca w postkomunistycznych społeczeństwach zaduma nad przeszłością jest symptomem zarówno pre- jak i postmodernistycznego kryzysu, oznaką chaosu i niepewności, pół świadomym i półnieświadomym zjawiskiem z zakresu psychologii mas, pojawiającym się głównie w starszym pokoleniu i w części już nieco zmęczonego pokolenia średniego. B. Nóvé, Wspomnienia z czasów samowładztwa, czyli samowładztwo pamięci. Przeł. J. Goszczyńska, w: Nostalgia. Eseje o tęsknocie za komunizmem. Red. F. Modrzejewski, M. Sznajderman. Wołowiec 2002, op. cit., s. 190.

7 J. Andruchowycz, Romans z uniwersum. Przeł. O. Hnatiuk, w: Nostalgia, op. cit., s. 61. 
formacyjnej po 1989 roku, nie zdołały jeszcze zniwelować skutków ówczesnego gigantycznego przedsięwzięcia propagandowego, które legło u podstaw zjawiska, na przykład, w Polsce określanego mianem gierkonostalgii, a na Bałkanach jugonostalgii.

Należy także podkreślić, że selektywny charakter ostalgii prowadzi do procesu odwrotnego, do zapominania. Ostalgia jest zapominaniem - twierdzi Simona Popescu, rumuńska pisarka i eseistka: „Im większa amnezja, tym większa nostalgia"8. Na przykładzie Rumunii, Popescu wskazuje, że ten typ ostalgii dotyczy tych, którzy w jej kraju wymazali lata osiemdziesiąte wspominając jedynie swój kraj z lat sześćdziesiątych, kiedy nastąpiło relatywne otwarcie, liberalizacja i poprawiła się sytuacja ekonomiczna.

Niepełne, wybiórcze pamiętanie może mieć i pewne racjonalne uzasadnienie, na przykład może być wynikiem radykalnej i nagłej zmiany zasad porządku społecznego, a tak właśnie można charakteryzować doświadczenie Jesieni Ludów. Jak podkreśla słowacki prozaik i publicysta Martin Šimečka, część jego rodaków miała

wystarczająco dużo powodów, żeby nostalgicznie wspominać czasy, kiedy ich życie miało znaczenie, ich pozycja społeczna była solidna, a pewność, że nigdy się to nie zmieni - niewzruszona jak skała. To właśnie jest wspólny klucz do nostalgii, którą nie bez powodu czuje nawet więcej niż połowa ludności Słowacji9.

W równym stopniu, a bodaj czy nie w większym, uwagi te odnoszą się do doświadczenia czeskiego, gdzie pamięci o poczuciu stabilizacji i bezpieczeństwa socjalnego na poziomie elementarnym towarzyszy zdystansowanie i obawa przed skutkami przemian. Wespół ze swoimi słowackimi krajanami normalizację przeżywają więc w poczuciu głębokiej ambiwalencji.

Ostalgia staje się „mechanizmem obronnym przeciwko przyspieszonemu rytmowi zmian oraz ekonomicznej terapii szokowej"10 trafnie konkluduje rosyjska slawistka Svetlana Boym. Jak widać, mechanizm ostalgii związany jest bardzo silnie ze sposobem odbierania współczesności.

Niebagatelną rolę w pojawieniu się wybiórczej pamięci mógł mieć także niepisany „zakaz wspominania socjalizmu” po 1989 roku. Jak zauważył Šimečka, skutkuje to właśnie fałszywymi wspomnieniami przeszłości budowanymi z przypadkowych elementów, na przykład $z$ wiecznie powtarzanych $w$ telewizjach krajów postkomunistycznych seriali z minionych dekad, czy obecności w przestrzeni me-

8 S. Popescu, All that Nostalgia. Przeł. J. Struzińska, w: Nostalgia, op. cit., 104.

${ }^{9}$ "Wiele osób przyznaje się do niej niechętnie, ponieważ widzą absurd sztucznego świata, w którym przeżyli sporą część swojego życia. Jednak nawet mimo świadomości absurdu trudno obronić się przed nostalgią. Jest to tęsknota za wrażeniem, że tamto ograniczone przez poprzedni ustrój życie miało większy sens niż dzisiaj, kiedy nie dławią go już żadne granice". M. Šimečka, 110 konarów. Realny socjalizm i ptynące zeń nauki. Przeł. L. Engelking, w: Nostalgia, op. cit., s. 144.

10 S. Boym, Nostalgia i postkomunistyczna pamięć. Przeł. L. Stefanowska, w: Nostalgia, op. cit., s. 273. 
dialnej gwiazd socjalistycznej muzyki pop ${ }^{11}$. Byłoby to w pewnym sensie "opłakiwanie drobnych przywilejów"12 - twierdzi Simona Popescu, rumuńska pisarska i eseistka. Ostalgię można uznać za formę reakcji na nasilone rozczarowanie. Frustracja trudami transformacji wzmaga potrzebę sentymentalnego wspominania.

Nieuchronnie pojawia się pytanie: jaki jest mechanizm tworzenia się tej iluzji, który każe współczesnym obywatelom krajów postkomunistycznych snuć nostalgiczne narracje, zaprzeczające $\mathrm{w}$ wielu przypadkach prawdzie historycznej, a niekiedy własnym, indywidualnym doświadczeniom.

Martin Šimečka uważa, że w nostalgicznym rozpamiętywaniu socjalistycznej przeszłości uruchomiony zostaje podobny mechanizm, jaki towarzyszy nostalgii za czasami dzieciństwa, które przecież wcale nie musiało być szczęśliwe ${ }^{13}$. Warunkiem dobrego wspominania musi być jednak nieprzekroczenie pewnego punktu krytycznego bolesnych doświadczeń. Jeśli zostanie on osiągnięty (wydaje się, że każde społeczeństwo wyznacza sobie własny punkt krytyczny), proces ostalgii nie zostanie uruchomiony. W krajach postkomunistycznych odnotowujemy brak nostalgicznego wspominania czasów terroru stalinowskiego. $Z$ zasady tej wyłamuje się jednak Rosja i kino rosyjskie ${ }^{14}$. Ponadto w Rumunii pokolenie urodzone około 1965 roku, którego tożsamość kształtowała się w latach osiemdziesiątych - czasach skrajnego kryzysu „złotej ery” Ceausescu - „łączyły (lub dzieliły) tylko wspólne wyrzeczenia, wspólne poczucie (...) [braku], poczucie skradzionej młodości"15.

Warto zwrócić uwagę, kto podlega sentymentalnemu wspominaniu. Oczywistym jest, że "prawdziwą silną tęsknotę odczuwają uprzywilejowani"16, ale najbardziej popularną w krajach postkomunistycznych jest tęsknota za „małym heroizmem przetrwania", który z każdego zwykłego obywatela czynił postać - na

11 Zob. M. Šimečka, 110 konarów. Realny socjalizm i płynace zeń nauki, op. cit., s. 148.

12 Zob. S. Popescu, All that Nostalgia, op. cit., s. 98.

${ }_{13}$ M. Šimečka, 110 konarów. Realny socjalizm i płynące zeń nauk, op. cit., s. 132.

${ }^{14}$ Svetlana Boym, szkicując sytuację w kinie rosyjskim od czasów pierestrojki, zauważa dwie silne tendencje $\mathrm{w}$ kinie odnoszącym się do przeszłości stalinowskiej. W okresie pierestrojki wyraziście zaznaczyła się linia, którą określiła jako kino "stalinowskiego kiczu” charakteryzujące się stylem eklektycznym. Jak podkreśla rosyjska badaczka: „Stylowa nieczystość i eklektyzm traktowane były jako gest antyutopijny falsyfikujący słynne style stalinowskiej przeszłości". (S. Boymová, Kýč a nostalgie v postsovětskem filmu, w: Film a dějiny 3. Politická kamera - film a stalinismus. Red. K. Feigelson, P. Kopal. Przeł. D. Čenék, T. Jirsa, L. Holubová Mikolašová, Praha 2012, s. 114). Z kolei w połowie lat 90. w kinie rosyjskim pojawiła się tendencja nostalgiczna zastępująca karnawałowe gry z kiczem. Filmy stylistycznie mniej eklektyczne poszukiwały nowego sposobu opowiadania, jednak bez dążenia do demistyfikacji stalinizmu (zob. s. 119). Boym nie używa pojęcia ostalgii, proponuje natomiast dla rosyjskiego fenomenu nazwę "glokalna nostalgia" w tym sensie, iż "globalny filmowy język oddany zostaje na służbę lokalnych mitów" (s. 120). Sztandarowym przykładem tego typu twórczości, jej zdaniem, są filmy Nikity Michałkowa, zwłaszcza Spaleni stońcem, 1994 i Cyrulik syberyjski, 1998.

${ }^{15}$ S. Popescu, All that Nostalgia, op. cit., s. 102.

16 S. Popescu, ibidem, s. 99. 
miarę swoich czasów - heroiczną. Sednem nostalgii byłaby tęsknota za „Idealnym $\mathrm{Ja}^{\prime \prime}$, za swoim wizerunkiem $\mathrm{w}$ tamtych czasach, prostym, jednoznacznym i w jakimś sensie niewinnym.

Wydaje się jednak, że największą grupę ludzi, którzy odczuwają przyjemność $\mathrm{w}$ powrotach do materialnej przeszłości komunistycznej, w pławieniu się w przedmiotach, obiektach z przeszłości, są młodzi ludzie, którzy nie pamiętają za wiele lub wręcz nic $z$ tamtej epoki. W tym przypadku może być to sygnał przezwyciężania pamięci o komunizmie. Nie musi więc wynikać z chęci powrotu do przeszłości, ale wręcz przeciwnie, z przekonania, że komunizm jest "epoką ostatecznie zamkniętą, definitywnie zakończoną", w którym odnaleźć można nawet "pewien urok (...) rodzaj <surrealistycznego> niewolnictwa"17. Młodzi ludzie postrzegają kulturę codzienną epoki komunizmu jako rodzaj absurdalnego skansenu pełnego nieprawdopodobnych kuriozów, fascynuje ich brzydota, tandeta i wszechogarniający kicz. Starsze pokolenia natomiast, jeśli sięgają po peerelowskie pamiątki, to czynią to tylko po to, by:" (...) przypomnieć sobie czasy, gdy mogli marzyć o świecie, który w końcu się ziścił, ale daleko jest mu do doskonałości (...) [tamtych] wyobrażeń" 18 .

Jak widać, sentymentalne wspominanie przeszłości sprzed przełomu, może mieć nie tylko różne nasilenia, przyczyny funkcjonowania, ale także powody, dla których praktykuje się nostalgiczne rytuały. Jeśli w Polsce, na Węgrzech, a także w Czechach i na Słowacji dominuje przede wszystkim zabawowy charakter ostalgicznego wspominania, to $\mathrm{w}$ niemieckim dyskursie pamięci, wykazuje nieco inny charakter. Aleida Assmann, rozprawiając nad różnymi aspektami pamięci, podkreśla także jej rolę, jaką może odgrywać w konstruowaniu projektu tożsamościowego $^{19}$. Na ten aspekt zwrócił uwagę niemiecki historyk Stefan Wolle, twierdząc, iż ostalgia współtworzy, zresztą dopiero po upadku państwa, „enerdowską tożsamość" 20 . Należy pamiętać, że zjednoczenie oznaczało także konieczność odrzucenia kultury wypracowanej w NRD, której wytwory lądowały na śmietnikach, czyniąc miejsce wymarzonym a niedostępnym do tej pory, dobrom zachodnim. Rzeczywiste a zarazem symboliczne odrzucenie spuścizny enerdowskiej było poniekąd odrzuceniem pamięci o niej, a przecież nie można funkcjonować bez jakiejkolwiek przeszłości. Postponowane w pierwszym odruchu przedmioty socjalistycznej kultury materialnej i duchowej, niebawem zaczęły powracać nie tyle na swoje pierwotne miejsca, ile przybierały charakter reprezentanta mitologizowanej przeszłości. Stały się naturalnym orężem w walce obronnej „Ossich”, którzy za

17 Ibidem, s. 107.

${ }^{18}$ P. Smoleński, Za komuny było lepiej czyli o kłopotach wspólnej podróży nad morze, w: Nostalgia, op. cit., s. 120.

19 A. Assmann, 1998 - Między historia a pamięcia, w: Pamięć zbiorowa i kulturowa, op. cit., s. 111.

20 Zob. S. Wolle, Wspaniaty świat dyktatury. Codzienność i władza w NRD 1971-1989. Przeł. E. Kazimierczak, W. Leder. Warszawa 2003, s. 25. 
Zjednoczenie zapłacili zepchnięciem do drugiej kategorii obywateli, bowiem zjednoczenie okazało się przymusowym i bezdyskusyjnym przyjęciem zachodnich wzorców, modeli i rozwiązań. Obrazowo wyjaśnia tę kwestię Magdalena SaryuszWolska:

Problem polegał więc na tym, że partia i jej ideologia były jedynymi filarami, na których opierała się enerdowska tożsamość. Również po zjednoczeniu obywatelom wschodnich Niemiec nie dane było budować poczucia narodowej wspólnoty w oparciu o państwo, które właśnie się odradza (jak było w przypadku Polski czy Węgier) lub powstaje (np. republiki nadbałtyckie), musieli natomiast bardzo szybko dostosować się do wzorców wypracowanych przez społeczeństwo zachodnioniemieckie. Na domiar złego Niemcy zachodni zaczęli traktować wschodnie landy jak kulę u nogi. Obietnice chadeckiego rządu, iż obszar byłej NRD rychło zmieni się w krainę mlekiem i miodem płynącą, nie spełniły sięe21.

Ranga nostalgicznej pamięci we wschodnich niemieckich landach, silne podstawy jej obecności, nie powinny jednak stwarzać wrażenia, że dyskurs nostalgiczny dominuje $\mathrm{w}$ niemieckim dyskursie przeszłości ${ }^{22}$. Zajmując istotne miejsce, ścierać się musi z równie silną refleksją rozliczeniową nad przeszłością enerdowską, która akcentuje inne doświadczenia z przeszłości: terror, przemoc, nieustającą inwigilację, masowe represje, któremu podlegało społeczeństwo, ale także współudział w systemie totalitarnym ogromnej liczby obywateli NRD.

Pytanie o miejsce ostalgicznej refleksji w dyskursach przeszłości prowadzonych w krajach byłego bloku wschodniego, wydaje się na tyle istotne, że warto kwestię tę rozpatrywać na przykładzie jej wyrazistej obecności w kinie środkowoeuropejskim.

\section{KINO SENTYMENTALNEGO WSPOMINANIA}

Interesujące jest, $\mathrm{w}$ jakim stopniu mechanizmy ostalgii wpłynęły na filmowy dyskurs o przeszłości uruchomiony przez kino czasu przełomu. Mamy tu do czynienia $\mathrm{z}$ bardzo różnym nasileniem tej tendencji $\mathrm{w}$ kinie Europy postkomunistycznej. Najwcześniej i najbardziej wyraziście zaznaczyła się w kinie postenerdowskim. Filmem, który upowszechnił nurt ostalgiczny był wspomniany już Good Bye, Lenin, 2003 Wolfganga Beckera, w sposób symboliczny zatrzymujący dawny świat, próbujący powstrzymać nadchodzące zmiany. Oto zagorzała enerdowska komu-

\footnotetext{
${ }^{21}$ M. Saryusz-Wolska, Ostalgia, "Tygiel Kultury" 2005, nr 9. http://www.tygielkultury.eu/7_9_ 2005/aktual

22 E. Fiuk, autorka pracy poświęconej współczesnemu kinu niemieckiemu, pomija w swych rozważaniach problem ostalgii analizując filmy dotykające problemu upadku muru berlińskiego. Zob. E. Fiuk, Inicjacje, Tożsamość, Pamięć. Kino niemieckie na przełomie wieków. Wrocław 2012.
} 
nistka $\mathrm{w}$ przeddzień upadku muru berlińskiego, zapada $\mathrm{w}$ kilkumiesięczną śpiączkę. Tymczasem zmiany wokół dokonują się błyskawicznie. Tysiące mieszkańców NRD w pierwszym euforycznym odruchu, niejako poświadczając zapoczątkowane przeobrażenia, przemeblowuje swoje mieszkania. Gestem tym, w sposób symboliczny, potwierdzano dokonujące się zmiany. Dzieci Christiane w pierwszym odruchu także poddały się fascynacji zachodnim designem, ale oto $\mathrm{w}$ trosce o zdrowie matki postanawiają przywrócić dawny wystrój pokoju, w którym leży chora, stworzyć coś na kształt skansenu, by po wybudzeniu nie przeżyła szoku kulturowego. Wszystkie coraz bardziej absurdalne zabiegi Alexa, syna Christiane służyć miały symbolicznemu przywróceniu wyidealizowego obrazu miejsca dzieciństwa, w którym nie tylko matka, ale i on sam czuł się swojsko i bezpiecznie.

Hans-Christian Trepte, analizując kino niemieckie dotykające problemu przeszłości komunistycznej, wskazał na kwestie niepewności socjalnej po zjednoczeniu, jako główną przyczynę wykształcenia się nurtu ostalgicznego potwierdzając tym samym tożsamościowe źródła sentymentalnego rozpamiętywania. Już w połowie lat 90. w filmach, które odwoływały się do rzeczywistości NRD udało się:

zaobserwować coraz wyraźniejsze różnicowanie pomiędzy państwem formalnie rządzonym przez Socjalistyczną Partię Jedności a faktyczną codziennością w NRD. Powoli narasta zrozumienie dla obywateli NRD i ujawniają się symptomy "ostalgii", czyli „rozjaśniania” jego szarej i ponurej rzeczywistości²3.

Potrzebę „rozjaśniania szarej i ponurej rzeczywistości” jak to określił Trepte zaspokajały filmy: Jedź trabancie, jedź! Petera Timma i Reinhardta Kloosa, 1990; Stoneczna Aleja, 1999 Leandera Haussmana; Bohaterowie tacy jak my, 1999 Sebastiana Petersona. Trepte podsumowuje krótko: „Humor, infantylność, zagmatwanie, momentami ograniczenie, a zarazem pobłażliwość dla NRD cechuje wiele powstałych w tamtych czasach filmów"24. Filmy te łączy coś jeszcze - perspektywa dziecięcego czy młodzieńczego narratora.

W 2004 roku Kanał RTL prezentował serial Meine schonen Jahre, który okazał się wschodnioniemieckim odpowiednikiem amerykańskiego serialu Cudowne Lata. Te odległe kulturowo historie łączyła konstrukcja bohatera, dorastającego chłopca, który z perspektywy dorosłego snuje pełne nostalgii opowieści o swoim dzieciństwie i dojrzewaniu. Przyjęcie optyki dziecięcej (młodzieńczej) pozwoliło zredukować codzienność do zupełnie innych aspektów niż te, które dostrzegłby dorosły. Istotne jest to, że dziecko czy młodzieniec nie musi formułować sądów o rzeczywistości, nie musi tego świata rozumieć, ani go dogłębnie analizować. Ta strategia

\footnotetext{
${ }^{23}$ H.-Ch. Trepte, O przezwyciężaniu socjalistycznej przeszłości NRD oraz „przełomu” w filmie niemieckim, „Porównania” 2007, nr 4, s. 132.

${ }^{24}$ H.-Ch. Trepte, O przezwyciężaniu socjalistycznej przeszłości NRD, w: Przeszłość w kinie Europy Środkowej i Wschodniej po roku 1989. Red. B. Bakuła, M. Talarczyk-Gubała. Poznań 2009, s. 81.
} 
pozwala również, jak wspomnieliśmy już wcześniej, bezkarnie idealizować czasy młodości. Wyraziście dostrzec to można w Słonecznej Alei prezentującej losy grupy chłopaków z podwórka, którzy swoje młodzieńcze marzenia konfrontowali ze zgrzebną rzeczywistością egzystencji pod berlińskim Murem. Jeden z głównych bohaterów w ostatniej scenie filmu wyznaje, że mimo wszystko nie zamieniłby swojej młodości na inną. Należy zaznaczyć, że tę zachowawczą optykę bardzo chętnie stosuje nie tylko niemieckie kino ostalgiczne ${ }^{25}$, ale także odnaleźć ją można w kinie czeskim i węgierskim.

Silnie polityzowany dyskurs nostalgiczny w Niemczech wydał na świat produkty komercyjne, które oswajają i nadają jakiś ludzki kształt tworowi, w którym trudno było doszukiwać się jaśniejszych stron. Należy jednak wziąć pod uwagę zastrzeżenia, jakie poczyniła Magdalena Sariusz-Wolska:

Pamiętajmy zatem, że ostalgia to tylko część dyskursu toczącego się wokół pamięci o NRD. Ta, w gruncie rzeczy, dość pogodna forma rozrachunku z przeszłością należy głównie do sfery kultury masowej i, jak na standardy niemieckie, jest dość wyjątkowa. Nasi zachodni sąsiedzi prowadzili do tej pory ciężkie debaty dotyczące przeszłości narodu, w których wypowiadali się wybitni intelektualiści. Tymczasem dość lekkie utwory nostalgiczne (zarówno film jak i literatura) są nowością w niemieckim dyskursie o historii. Nie sposób było ironizować na temat zbrodni nazizmu czy II wojny światowej, ale NRD nadaje się do tego doskonale ${ }^{26}$.

Problematyka przeszłości enerdowskiej podejmowana przez kino niemieckie nie zamyka się jedynie do filmów realizowanych w ramach nurtu nostalgicznego. Po zjednoczeniu wyprodukowano także filmy, które uniknęły tendencji idealizacyjnej $\mathrm{w}$ prezentowaniu rzeczywistości byłej NRD ${ }^{27}$. Problemem pozostaje jeden z najbardziej znanych i niezasłużenie cenionych filmów niemieckich ostatnich lat, Życie na podstuchu (2006) Floriana von Donnersmarcka. Głównym bohaterem jest funkcjonariusz Stasi, który całe życie poświęcił na inwigilację pewnego znanego artysty-dysydenta. Początkowo skrupulatny, perfekcyjny urzędnik wykonywał swoją pracę bezrefleksyjnie, nie dostrzegając w swoich działaniach nic amoralnego, z czasem jednak w tym wzorowym ubeku dokonała się niezrozumiała dla widza moralna przemiana, w efekcie której, poświęca własne życie, by ratować swoją wieloletnio inwigilowaną ofiarę. Ckliwe zakończenie filmu relatywizuje etyczny wymiar działalności funkcjonariuszy Stasi. Pojawia się pytanie, czy nadal mamy do czynienia z procedurą „rozjaśniania ponurej rzeczywistości” czy może już przekroczeniem dopuszczalnej granicy swobodnego manipulowania pamięcią.

\footnotetext{
${ }^{25}$ Szarzej pisała na ten temat E. Kledzik, Antybohaterowie. Studium o dwóch figurach komunizmu, w: Przesztość w kinie Europy Środkowej i Wschodniej po roku 1989, op. cit., s. 99-109.

${ }^{26}$ M. Saryusz-Wolska, Ostalgia, op. cit.

${ }_{27}$ Pisze na ten temat: H.-Ch. Trepte, O przezwyciężaniu socjalistycznej przeszłości NRD, w: Przeszłość w kinie Europy Środkowej i Wschodniej...op. cit.
} 


\section{CZESKA OSTALGIA}

W czeskiej refleksji nad kinem ostalgicznym, jeszcze do niedawna dominowało przekonanie, iż zjawisko to należałoby postrzegać jedynie jako produkt kultury popularnej, i nie uczestniczy w dyskursie o przeszłości. Dzisiaj jednak stawiane jest w Czechach coraz częściej intrygujące pytanie: na ile należałoby ostalgię uznać za zjawisko współtworzące postnormalizacyjną tożsamość w tym kraju.

O symptomach pogrobowego zwycięstwa skompromitowanego systemu wspomina także czeski historyk młodszego pokolenia, który postawił kontrowersyjną tezę, iż współczesne Czechy zmierzają w stronę neonormalizacji, odchodząc od wizji społeczeństwa demokratycznego projektowanego w polistopadowym zwycięstwie ${ }^{28}$.

Współcześni ostalgicy to przede wszystkim generacja Husakovych dzieci, twierdzi Ina Marešová29, które mają jedynie w pamięci w miarę dobrze zaopatrzone sklepy, rzekomy brak bezrobocia i bezdomności, a także kolorowy świat gwiazd socjalistycznej kultury popularnej. Czeski krytyk filmowy Jaroslav Pinkas zwraca uwagę, iż w filmowym przekazie ostalgicznym wybiórcze traktowanie wspomnień prowadzi do eliminowania tych wszystkich, które związane były z przeżyciami traumatyzującymi. „Ostalgia, pisze Pinkas, to różowy płaszcz, który społeczeństwo ubiera, aby zakryć swoją zupełnie nieelegancką bieliznę"30. Wspominanie i skupianie się na nieideologicznych aspektach przeszłości, takich jak: rodzina, praca, wolny czas, mieszkanie tak charakterystyczna dla narracji nostalgicznych, okazuje się ucieczką od poważnego namysłu historycznego czy politycznego nad epoką komunizmu. Jakkolwiek niemieckie kino ostalgiczne prezentuje najbardziej reprezentatywną formę tęsknoty za socjalistyczną przeszłością, to jednak należy jeszcze raz podkreślić, że jest to jeden z nurtów w kinie niemieckim dotykającym problematyki enerdowskiej. W przypadku Czech, sytuacja jest zgoła odmienna. Większość filmów o przeszłości do niedawna realizowane były w ostalgicznej optyce, a wśród nich: Ta naše písnička česká II (1990) Víta Olmera, Obecná škola (1991) Jana Svěráka, Diky za každé nové ráno (1994) Milana Šteidlera, Báječná léta pod psa (1997) Petra Nikolaeva (według powieści Michála Vievegha), Pelíšky (1999) Jana Svěráka, Rebelové (2001) Filipa Renča, Pupendo (2003) Jana Hřebejka, Anglické jahody (2008) Vladimíra Drhy, Občanský průkaz (2011) Ondřeja Trojana. Fenomenem samym dla siebie okazuje się serial telewizyjny Výprávéj (od roku 2009), który stanowi opowieść o losach kilku rodzin ujmowanych na tle waż-

${ }_{28}$ Zob. M. Pulmann, Konec experimentu. Přestavba a pád komunizmu v Československu. Praha 2011, tu szczególnie ss. 225-227.

${ }_{29}$ Zob. I. Marešová, Svůdný klam poprelikvií. Obzvlášt vydařený ostalgický export. "Cinepur" 2011, nr 11-12.

${ }^{30}$ Zob. J. Pinkas, Jak hrozná doba! Jak krásná léta! Ostalgie jako vzpomínání na normalizaci. Tłum. własne - D.D. „Cinepur” 2011, nr 11-12, s. 67. 
nych wydarzeń historycznych. Akcja rozpoczyna się w 1964 roku a kończy na 1989. Żadne z wydarzeń historycznych, łącznie z Praską Wiosną i inwazją Wojsk Układu Warszawskiego nie zdominowały najważniejszego przesłania filmu, którym okazuje się mała historia skupiona na trudach i radościach codziennej egzystencji $\mathrm{w}$ socjalistycznej ojczyźnie. Ledwie zarysowany kontekst historyczny wspomagany jest $\mathrm{w}$ każdym odcinku fragmentami ówczesnych Kronik Filmowych, które, podobnie jak polskie, miały charakter przede wszystkim propagandowy. Wykorzystywanie ich dzisiaj jako źródła informacji o przeszłości rodzi zdziwienie, podobnie jak ogromna popularność serialu wśród czeskich i słowackich widzów.

Wspomniane filmy świadomie banalizują ówczesną rzeczywistość, a wydarzenia historyczne stanowią tu jedynie tło dla osobistych perypetii bohaterów, wyciszając w znacznym stopniu grozę wydarzeń historycznych, wokół których osnuta została fabuła.

Kino ostalgiczne, którego głównym założeniem jest zachowanie ideologicznej neutralności, poszukuje usprawiedliwienia dla swoich zaniechań. Realizacja filmów w konwencji określonego gatunku wyjaśnia niejako daleko idące uproszczenia kontekstów. Większość filmów nurtu ostalgicznego: czeskich, niemieckich, polskich, węgierskich, to komedie, gdzie reguły gatunku rządzą sposobem ukazywania rzeczywistości, nawet tej najbardziej dramatycznej. Aktywizowany jest także gatunek musicalu. W Czechach zrealizowano Šakali leta Jana Hřebejka rozgrywający się w latach 50. oraz Rebelové Filipa Renča, którego akcję umieszczono w 1968 roku. Formuła musicalu chronić miała niejako przed zarzutami banalizacji świata, braku wizji historycznej. Tendencję ucieczki w kino gatunku potwierdza także węgierski musical Kociaki (1997) Pétera Tímára, który wykorzystał bezpieczną konwencję musicalu, by przywołać jedynie miłe wspomnienia z lat 60 .

\section{WĘGIERSKIE OSTALGIZOWANIE}

Zjawisko ostalgii odnotowano także w kinie węgierskim. Kwestie te podnosiła w polskim filmoznawczym piśmiennictwie Aleksandra Muga, rozpatrując sposoby obecności czasów Kádára w filmie węgierskim po 1989 roku ${ }^{31}$. Uzasadnienie jego zaistnienia i rozwoju wydają się bliskie doświadczeniom nie tylko niemieckim. Zdaniem autorki, odnoszą się do trudów transformacji, rozczarowania współczesnością, która nie spełniła wszystkich oczekiwań. Najczęściej obiektem sentymentalnego wspominania były lata 60. czasy względnego dobrobytu na Wę-

${ }^{31}$ A. Muga wskazała na filmy odwołujące się w sentymentalnej formule do lat 60.: Nigdy nie umrzemy (1993) i Samba (1996) Róberta Koltaiego; do lat 70. i 80.: Mała podróż (2000) Mihálya Buzása i György Pálosa, Ferenca Töröka Plac Moskwy (2001), Naprzód! (2002) Daniela Erdélyego. 
grzech, które w trudnych chwilach, niepopularnych przedsięwzięć transformacyjnych jawić się mogły jako przyjazne socjalnie i bezpieczne ekonomicznie:

Wzmożoną nostalgię za epoką Kádára po przełomie, najczęściej tłumaczy się kryzysem społeczno-ekonomicznym, jaki towarzyszył przemianom. Transformacja wiązała się z licznymi utrudnieniami życiowymi (masowe bezrobocie, niepewność egzystencjalna, konieczność dostosowania się do nowych wymogów rynkowych) i przyniosła na Węgrzech głównie rozczarowanie. Ciężar poniesionych ofiar osobistych każą poddać w wątpliwość wartość zachodzących procesów i pobudził mechanizm selektywnego, idealizującego działania pamięci ${ }^{32}$.

Béla Nóvé potwierdza diagnozę Mugi pisząc:

Czy powinno nas [...] dziwić, że mając już dość sprawiającego wrażenie beznadziejnego, wielkiego "historycznego" marszu, wiele osób tęskni do upiększanego dziś, wątpliwego azylu przeszłości? Do świata wakacyjnych miłości, i obozów pionierskich, weekendowych "ogródków hobbystów" i trabantowi-wartburgowych wschodnioeuropejskich „objazdów przemytniczych", do czasów, kiedy wszystko było jeszcze na pozór bardziej jednolite. Przejrzystą, a wystarczającą rekompensatą za brak wolności miała być niezliczona ilość politycznych żartów w radiowym kabarecie ${ }^{33}$.

Nóvé podsumowywał:

w latach dziewięćdziesiątych powstawały dziesiątki humorystycznych lub cierpko nostalgicznych filmów, które, w pamięci ogółu- zawsze skłonnej do samooszukiwania się - ówczesną łagodną" dyktaturę chcąc nie chcąc czyniły jeszcze łagodniejszą ${ }^{34}$.

\section{POLSKIE PRZYWOŁYWANIE SOCJALISTYCZNEJ PRZESZŁOŚCI}

Interesujące, że filmy wspominające peerelowską przeszłość jako bardziej zabawną niż groźną, która epatuje przedmiotami kojarzącymi się z epoką, pojawiły się $\mathrm{w}$ polskim kinie jedynie okazjonalnie, za sprawą młodych reżyserów: Oskara Kaszyńskiego, który wyreżyserował film Segment'76 (2002), Wiesława Palucha, autora filmu Motór (2004). Szczególnym przypadkiem wydaje się koprodukcja polsko-czeska Operacja Dunaj (2009) w reżyserii Jacka Głomba. Komiczna historia załogi polskiego czołgu, która uczestniczy w inwazji na Czechosłowację w 1968 roku, perypetie załogi $\mathrm{w}$ małym czeskim miasteczku i wyraźne nawiązania do

\footnotetext{
32 A. Muga, Słodko-gorzkie reminiscencje „miękkiej dyktatury” Janosa Kádára w kinie węgierskim. „Porównania" 2010, nr 7, s. 158.

33 B. Nóvé, Wspomnienia z czasów samowładztwa czyli samowładztwo pamięci..., op. cit., s. 194.

${ }^{34}$ B. Nóvé, Wspomnienia..., op. cit.
} 
peerelowskiego serialu Czterej pancerni i pies, okazały się niefortunnym przedsięwzięciem budzącym wątpliwości natury moralnej. Oto bowiem (chcąc nie chcąc), spadkobiercy współuczestników akcji okupacyjnej 1968 roku, pozwolili sobie na żartobliwy i rubaszny ton wobec jednego z najbardziej dramatycznych doświadczeń południowych sąsiadów. Próba przejęcia charakterystycznego (hrabalowskiego?) stylu opowiadania o wydarzeniach dramatycznych, tragicznych, wzniosłych, nie powiodła się.

Kino polskie nie poddało się ostalgizacji $\mathrm{w}$ takim stopniu jak $\mathrm{w}$ innych krajach byłego bloku wschodniego. Stosunkowo słaba obecność tendencji ostalgicznych $\mathrm{w}$ kinie równoważona jest silną jej reprezentacją $\mathrm{w}$ innych mediach, na przykład $\mathrm{w}$ wizualnych przekazach reklamowych, chętnie odwołujących się do pamięci przeszłości, bazującej na rzewnych skojarzeniach z przedmiotami młodości. Strategie sentymentalnego wspominania widoczne są także $\mathrm{w}$ świecie wirtualnym Internetu, gdzie pojawiły się liczne strony wspominające PRL, sklepy internetowe z przedmiotami sprzed kilkudziesięciu lat, również interaktywne Muzea Komunizmu ${ }^{35}$. Do obiektów ostalgicznych zaliczyć można także liczne publikację dotyczące PRLu, skupiające się na pełnym dystansu i humoru opisie charakterystycznych artefaktów z epoki. Na przykład autorzy Matej encyklopedii obciachu, we wstępie zaznaczają:

Nasza książka jest subiektywna i stronnicza. A w dodatku - momentami - złośliwa. Jej lektura będzie dla jednych czystą rozrywką, u innych podniesie poziom intelektualnej adrenaliny. I o to chodzi! Tym, którzy się z nami nie zgadzają (a oby ich było jak najwięcej), kłaniamy się nisko ${ }^{36}$.

Filmy ostalgiczne, które w najnowszej historii polskiego kina nie zajmują znaczącego miejsca, dowodzą jak pamięć kulturowa tworzona jest $\mathrm{z}$ jej zasobów marginalnych, elementów nieistotnych, które służyć mogą jedynie do budowania przekazu popkulturowego. Ten typ ostalgii wynikać może z poczucia bezpieczeństwa, z przekonania, że wybiórcze operowanie jedynie już muzealnymi eksponatami, świadoma niereprezentatywność elementów, z których buduje się narracje o przeszłości ma charakter niezobowiązującej zabawy. Posługując się ustaleniami Aleidy Assmann, tego typu kino ostalgiczne korzysta z elementów, wyciągniętych ze zdefunkcjonalizowanych odpadów pamięci, które teraz nabierają nowego zna-

${ }^{35} \mathrm{Na}$ ten temat pisała M. Golonka-Czajkowska w tekście Podróż do krainy zwanej Nowa Huta, czyli o komunizmie jako atrakcji turystycznej i Z. Grębecka: Między śmiechem a nostalgia - powroty do komunistycznej przeszłości, w: Popkomunizm. Doświadczenie komunizmu a kultura popularna. Red. M. Bogusławska, Z. Grębecka. Kraków 2010. Analizę fenomenu nostalgii za przeszłością peerelowską podjęły się m.in. M. Talarczyk-Gubała w tekście Kultura popularna $i$ nostalgia za komunizmem czy K. Wajda, 07 wciąż się zgłasza, „Kultura Popularna” 2004, nr 4.

${ }^{36}$ Zob. Mata encyklopedia obciachu. Praca zbiorowa. M. Rychlewski, A. Januszkiewicz, P. Gogler, M. Klajn, M. Wesołowski, Poznań 2008. (Fragment tekstu promocyjnego). 
czenia. Artefaktem jako nośnikiem nowej pamięci stały się przedmioty i przestrzenie, na przykład: w polskim filmie tytułowy „motór”, i meblościanka zwana segmentem, w niemieckim Jedź trabi, jedź! - trabant, ogórek konserwowy w Good Bye, Lenin! ${ }^{37}$, w filmie węgierskim przestrzeń tytułowego placu, który jednak dzisiaj nie nazywa się już Moskiewski, ale Kálmana Szélla, czy też praskie Dejvice z socrealistycznym hotelem Intercontinental w filmie Šakali leta. Przywołana pamięć przedmiotów i przestrzeni sprzed przełomu poddana jest przemianie znaczeń. Wprowadzone $\mathrm{w}$ nową, wykreowaną fikcyjnie rzeczywistość filmową przestają świadczyć o przeszłości. Za przykład niech posłuży Trabant. W tamtych czasach jego posiadanie traktowane było jako upokarzająca konieczność, skoro poza zasięgiem były osiągnięcia światowego rozwiniętego przemysłu motoryzacyjnego, teraz przeobraził się $\mathrm{w}$ obiekt pożądania ekscentrycznych zachodnich kolekcjonerów, zalecający się jedynym w swoim rodzaju atrakcyjnym egzotyzmem.

\section{BEZPOWROTNOŚĆ W KINIE JAKO REAKCJA NA OSTALGIĘ}

Jeśli ostalgia budowana jest na sentymencie do pewnych aspektów przeszłości to zaprzeczenie ostalgii, które nazywać będziemy bezpowrotnością znajduje swoje źródło w resentymentach do równie wybiórczo traktowanej przeszłości.

Simona Popescu poszukując jakiegoś określenia na zaprzeczenie ostalgii zaproponowała pojęcie nostalgii zbuntowanej,

która nie każe (...) wracać do przeszłości, lecz sprawia, że starasz się przeżyć na nowo czas, który ci ukradziono, odzyskać wszystko: zakazane książki, muzykę, to, co się działo na świecie lat osiemdziesiątych, do którego nie było wówczas dostępu ${ }^{38}$.

Sugestie rumuńskiej autorki pozwalają ujawnić zjawisko, który nazywać będziemy bezpowrotnością, z jednej strony przejawiające się $\mathrm{w}$ niechęci do wspominania, ucieczką od przeszłości $\mathrm{w}$ prezentyzm, ale $\mathrm{z}$ drugiej strony sięgające do najciemniejszych doświadczeń czasów komunizmu, czego najpoważniejszym przejawem będzie rozpamiętywanie zbrodni komunistycznych. Bezpowrotność, jak już wspomniałam, ma także charakter pamięci wybiórczej, która każe się skupić na wadliwości systemu i jego skutkach. Często pomijane są te prywatne

37 „Spreewald to kolebka komunistycznego ogórka kiszonego. Który ponoć smakuje najlepiej na świecie. W filmie Goodbye, Lenin! jest scena, kiedy główny bohater Alex musi kupić dla swojej chorej matki słoik tychże ogórków. Kiedy okazuje się, że w sklepach już ich nie ma, postanawia włożyć inne ogórki do oryginalnego słoiczka. Różnicy w smaku chyba nie ma, ale chodzi o zasadę. A może o przyzwyczajenia konsumentów do wybranych i sprawdzonych marek". I. Rodzeń, (N)ostalgia za NDR. (Analiza społeczna). http://www.niemcy-online.pl/spoeczestwo/193-nostalgia-za

38 Zob. S. Popescu, All that Nostalgia, op. cit., s. 103. 
wspomnienia, które w sposób bezpośredni nie poświadczają charakteru systemu, preferowane są natomiast te, które stanowią świadectwa potwierdzające praktyki niedemokratycznego systemu: spustoszenia dokonane $\mathrm{w}$ sferze mentalnej i obyczajowej, wymiar duchowego i materialnego ubóstwa obywateli, wreszcie upokarzające uciążliwości życia codziennego.

„Film český je hezký” (czeski film jest ładny) mawiają Czesi. To właśnie ta niekontrowersyjna "ładność" zachwyciła członków Akademii, którzy nagrodzili Oscarem Kolę Jana Svěráka w 1996 roku. Jego pojednawczy charakter przyjęty został przez zachodnich widzów z wdzięcznością i ulgą. Dla czeskiego kina otworzono podwoje europejskich kin. Filmy Jana Hřebejka, Jana Svěráka, wczesne filmy Petra Zelenki podbijały serca europejskiej publiczności znużonej środkowoeuropejskim kinem zaangażowanym społecznie, prowadzącym poważne dyskusje nad swoimi dziejami. Już od kilku lat środowiska czeskich historyków i krytyków filmowych, wyrażały niepokój stanem czeskiego kina, które ich zdaniem, zamknęło się $\mathrm{w}$ formule ostalgicznych opowieści o przeszłości. Bezpiecznej, lubianej przez widzów, ale coraz bardziej ujawniającej swoją jałowość i banalność. Dyskusje nad stanem czeskiego kina ostatnich lat wpisują się w coraz lepiej słyszalny dyskurs publiczny nad stosunkiem do czasów normalizacji. Ostatnie lata przyniosły nieco poważniejszy namysł nad przeszłością czechosłowacką w czeskim kinie. Symptomami nowego trendu są Kavasakiho Růže (2009) Jana Hřebejka, które włączyły się w środkowoeuropejski dyskurs lustracyjny czy Pouta (2010) Radima Špačka - polemizujący niejako z niemieckim obrazem Życie na podsłuchu. Filmy te każą dostrzec nową tendencję $\mathrm{w}$ sposobie przedstawiania przeszłości.

Rodzący się namysł nad istotą ostalgii zmienia nieco w kinie środkowoeuropejskim sposób ujmowania przeszłości. Coraz silniej uobecnia się idea pamięci bezpowrotnej. Operowanie artefaktami z epoki socjalizmu tym razem wyzwalają opowieści o tym "tak jak było". Chodzi o uruchomienie pamięci na wzór proustowskiej magdalenki, która przywołuje gorzki smak tamtych czasów. Charakterystyczne jest nieaktywizowanie perspektywy współczesnej, która powoduje postrzeganie ówczesnej rzeczywistości w sposób niejako przefiltrowany przez późniejsze doświadczenie. Właśnie ta specyficzna dla ostalgii perspektywa dnia dzisiejszego, która na przykład pozwala Czechom spojrzeć na epokę normalizacji z dystansem, komediowo i z przymrużeniem oka, wynika z wiedzy nabytej później: „że właściwie nic takiego się nie stało, bo przecież wszystko skończyło się dobrze". Wyłączenie tej korygującej perspektywy, pozwala na wypreparowanie z pamięci tamtych i tylko tamtych wspomnień, zrekonstruować ówczesny styl odbioru rzeczywistości.

Poszukując filmów realizujących założenia bezpowrotności wskażmy na ukraiński film Kiry Muratowej Syndrom asteniczny (1989), gdzie nieodległa przeszłość, zaledwie sprzed paru miesięcy realizowana była jeszcze $\mathrm{w}$ traumie niedawnych doświadczeń. Obraz spustoszeń moralnych i materialnych po komunizmie, nabrał tu charakteru apokaliptycznego, o ogromnej sile rażenia. 
Ideę bezpowrotności, odwrotu od sentymentalizmu w sposobie pokazywania Peerelu urzeczywistnił film Wojtka Smarzowskiego Dom zły, 2010. Akcja rozgrywa się w latach 80., ale opowiedziana historia stała się tylko pretekstem, by uruchomić emocje, nastroje związane z ponurym czasem stanu wojennego. Efekt autentyzmu, przywołania niewyretuszowanych wspomnień, Smarzowski uzyskał uruchamiając nieomal podprogowe pokłady pamięci przy pomocy wyglądu bohaterów, sposobu ich zachowania, mówienia.

Odrzucenie idealizowanej przeszłości zrealizowały także podobne w charakterze i problematyce dwa filmy: słowacki Muzyka w reżyserii Juraja Nvoty, 2008 i polski - Wszystko co kocham, 2010 Jacka Borcucha. Oba filmy opowiadają o podobnych problemach $\mathrm{w}$ podobnych czasach. W polskim filmie młody chłopak marzy o graniu rocka, który w latach stanu wojennego był w Polsce uosobieniem idei wolnościowych, w słowackim nieco starszy bohater, w podobnych latach snuje równie nierealne marzenia o byciu prawdziwym jazzowym muzykiem. Oba filmy odwołują się do konwencji kina inicjacyjnego, chociaż konstrukcja fabularna sprzyjała przyjęciu optyki nostalgicznej, reżyserom udało się uniknąć idealizacyjnego fałszowania doświadczeń epoki.

Bezdyskusyjną niechęć do czasów dyktatury Ceausescu demonstrują filmy rumuńskiej Nowej Fali, z początku nowego tysiąclecia. Warto zaznaczyć, że $\mathrm{w}$ kinie rumuńskim nie odnotowano zjawiska nurtu ostalgicznego. Siła kina realizującego ideę bezpowrotności budowana jest, między innymi, przez całkowity brak fetyszyzacji przedmiotów i przestrzeni, które zachowały swój odrażający wymiar (np. mieszkanie pana Lazarescu w filmie Śmierć pana Lazarescu (2005) Cristiego Puiu, szare ulice Bukarsztu, wystrój akademika w 4 miesiace, 3 tygodnie, 4 dni (2007) Cristiana Mungiu.

12:08 na wschód od Bukaresztu (2006) Corneliu Porumboiu stanowi natomiast swoisty radykalny manifest antyostalgiczny, którego tematem stała się zwodnicza pamięć o wydarzeniach rewolucyjnych podważająca, zdaniem reżysera, możliwość snucia jakiejkolwiek wiarygodnej refleksji o przeszłości.

$\mathrm{Z}$ tej perspektywy interesującym obrazem okazuje się komedia Juliusza Machulskiego Ile waży koń trojański (2010), która w konwencji gatunku opowiada o koszmarze pewnej czterdziestolatki, marzącej o powrocie do lat swojej młodości. Kiedy jednak dziwnym trafem jej marzenie się spełnia, lata 80., w których się znalazła, ujawniły przed nią przede wszystkim swoje koszmarne oblicze, którego pamięć po latach życia w dynamicznie modernizującym się, niepodległym kraju, jakby się zatarła. Teraz odżyła, na skutek owej nieprawdopodobnej podróży w czasie. Film Machulskiego stanowi żartobliwą krytykę ostalgii opartej na selektywnej pamięci i tworzeniu fantazmatów przeszłości. Refleksja nad pamięcią o komunistycznej przeszłości, zrealizowana w lekkiej formule komediowej znalazła swoje potwierdzenie $\mathrm{w}$ niezwykle ciekawym, $\mathrm{z}$ tego punktu widzenia, filmie dokumentalnym czeskiej reżyserki Lindy Jablonskej Witajcie w KRLD! (2009). Gru- 
pa czeskich turystów wybrała się na wycieczkę do Korei Północnej, w którym system komunistyczny jest nadal żywy, panuje kult jednostki, zasadą jest łamanie prawa człowieka. Turyści nie mogli korzystać z telefonów komórkowych i kamer, znajdowali się pod stałą i ścisłą kontrolą funkcjonariuszy służb specjalnych, oglądali świat jedynie taki, na jaki pozwolili im gospodarze - iluzoryczny i pieczołowicie spreparowany. Dokumentalistka obserwowała grupę swoich rodaków i ich reakcje. Początkowo dominowało zaciekawienie i zabawna fascynacja światem, który przypominał im ich własny kraj sprzed kilkudziesięciu lat. W krótkim czasie ostalgiczne emocje, $\mathrm{z}$ jakimi wybrali się $\mathrm{w}$ tę podróż $\mathrm{w}$ przeszłość ustą̧iły przerażeniu, poczuciu zagrożenia, powróciły najgorsze wspomnienia $\mathrm{z}$ nieodległych czasów, od których tak bardzo się już oddalili. Powrót do przeszłości zamiast być przygodą sentymentalną, okazał się powrotem do koszmaru, wyprawą pełną grozy, przywołującą najgorsze wspomnienia z komunistycznej Czechosłowacji. Jeszcze inną strategię bezpowrotności realizuje polski film Rewers (2009) w reżyserii Borysa Lankosza występując przeciwko, ostalgizowanej w popkulturze ostatnich lat, estetyce socrealistycznej. Film rozgrywający się w latach stalininowskich zrezygnował z naturalnego, wydawać by się mogło, scenograficznego sztafażu lat pięćdziesiątych, by poprzez uruchomienie filmowych tradycji ekspresjonizmu i kina noir, odejść od utartego, stereotypowego postrzegania tamtych doświadczeń, pozwalając zobaczyć tamte czasy, ludzi i ich dramaty w odmiennym oświetleniu.

Ostalgia i bezpowrotność, to dwie strategie użycia pamięci organizujące opowiadanie o przeszłości w kinie po przełomie 1989 roku. Mam oczywiście świadomość, że nie są to jedyne sposoby użycia pamięci w kinie czasów transformacji. Poza zainteresowaniem pozostało kino rekonstruujące przeszłość przy pomocy źródeł historycznych, ale także z "historią brązowniczą" czy realizujące aktualną "politykę historyczną".

Filmowe realizacje ostalgii, będące częścią współczesnej popkultury, bawią się elementami, które uznane zostały, w ramach ustalonej konwencji, za reprezentatywne dla epoki socjalizmu. Problem rodzi się wtedy, gdy ostalgiczne widzenia przeszłości zastąpić mają debatę historyczną, kiedy stają się istotnym, niekiedy konstytutywnym elementem dyskursu tożsamościowego. Idea bezpowrotności realizowana $\mathrm{w}$ kinie rozprawiającym o przeszłości, stara się równoważyć, pozbawionymi fałszującego sentymentalizmu świadectwami swoich czasów, wspomnienia generujące wyidealizowane obrazy, produkty nostalgicznej pracy pamięci. Swoiste napięcie, które wytwarza się dzięki obecności w filmowym dyskursie o przeszłości obu nurtów, stanowi jeden z licznych świadectw fenomenu kina czasów transformacji a jednocześnie bardzo silnie wpisuje się w problematykę usytu- 
owaną na jednym z obszarów dyskursu postzależniościowego ${ }^{39}$, który między innymi, jak wskazuje Ryszard Nycz podejmuje „refleksję nad doświadczeniem i mentalnością (zbiorową i jednostkową) (...) po PRL-u"40 w jego historycznopolitycznym wymiarze. W filmowym nurcie ostalgicznym ujawniają się niezwykle skomplikowane tendencje. Próba zerwania z opresyjną przeszłością, załagodzenia jej traumatycznego obrazu umożliwić ma nieresentymentalny zwrot ku przyszłości, jednak ta selektywna pamięć wikła się w zapominanie niebezpiecznie deformujące rejestry społecznej pamięci. Odpowiedzią na ostalgiczne fantazmaty staje się kino akcentujące niechęć do wyidealizowanych obrazów przeszłości przybierające różne formy przezwyciężania idealizacji minionych czasów.

${ }^{39}$ R. Nycz wyróżnia obszary refleksji naukowej nad polskim dyskursem postzależnościowym, przy czym, rozstrzygnięcia te w dużej mierze adekwatne są do doświadczeń innych krajów byłego bloku wschodniego. Krakowski badacz wydziela cztery pola badawcze obejmujące: problematykę teoretyczno-metodologiczną, polityczno-historyczną, społeczno-kulturową, typologiczno-antropologiczną.

${ }^{40}$ R. Nycz, Wprowadzenie. „Nie leczony, chroniczny pogłos”. Trzy uwagi o polskim dyskursie postzależnościowym, w: Kultura po przejściach, osoby z przeszłościa. Polski dyskurs postzależnościowy - konteksty i perspektywy badawcze. Red. R. Nycz. Kraków 2011, s. 8. 